\title{
BALANCED ECONOMIC GROWTH FROM THE STANDPOINT OF MODERN GROWTH THEORIES
}

\author{
UDC 330.34
}

\section{Srđana Dragomirović}

\author{
Faculty of Economics, University of Niš, Serbia
}

\begin{abstract}
For decades, world economy has been going through certain processes which vary from expansion to stagnation, and vice versa. For this reason, the factors or causes of economic growth are the key question which dates from the 1770s and Adam Smith's landmark work "An Inquiry into the Nature and Causes of the Wealth of Nations". Integrated through world economy, national economies are going through some of the changes which can be explicitly explained by observing the quality of economic growth. Thus, there are regions with sustainable development and balanced economic growth; on the other hand, there are expanding economies which are designated as developing countries. Distortion of world economy, observed through economic growth and inequality of national economies, from the standpoint of economic theories, can be explained by various models of economic growth.
\end{abstract}

Key words: economic growth, balanced economic growth, inequality, economic growth models.

\section{INTRODUCTION}

The complexity of economic structure stems from the background of dynamic economic multifaceted relations, which lead to both quantitative and qualitative economic growth. Thus, the quantitative economic growth, measured by the increase of the gross domestic product (GDP), is the consequence of an adequate qualitative growth, which is reflected in structural changes.

The competitive force of the capitalist economic development was reflected in balanced economic growth, which was based on increased productivity of industrial production and competitive market mechanisms. However, nowadays, that paradigm has been undermined by the development of information technologies, and economic

Received February $21^{\text {st }}, 2017$ / Accepted September $26^{\text {th }}, 2018$

Corresponding author: Srđana Dragomirović, Ph.D. student, Faculty of Economics, University of Niš, Trg kralja Aleksandra 11, 18000 Niš, Republic of Serbia

E-mail: srdjapn@yahoo.com 
theoreticians encounter new challenges in defining the mechanisms of economic growth in modern society.

\section{The NeOClassical Model of ECONOMIC Growth}

In traditional neoclassical models of economic growth, the differences in quality of economic growth between countries are determined by observing the accumulation factors. According to Solow (1956), disparity expressed by income per capita is based on difference in saving rates; according to Cass and Koopmans (1965), it is based on preferences and exogenous parameters such as total productivity growth and technical progress (Acemoglu, Johnson, Robinson, 2004: 1).

For a relatively long period of time, Solow's model of economic growth was the leading model of economic growth of neoclassical theory. Along with the existing factors of economic growth: natural resources, labor and capital, Solow's model incorporated technology as another factor of economic growth. Solow determines the national savings rate and the population rate from the standpoint of exogenous approach. The emphasis is on the real sector in economy, which is determined by full employment. Technology is regarded as a public good (asset) which is equally accessible to all economic actors in the society, characterized by perfect competition (Cvetanović, Leković, 2012: 189).

Neoclassical models of economic growth start from the exogenous point of view in assessing long-term economic growth. Nevertheless, the exogenous approach to examining economic growth has its shortcomings and weaknesses. Solow states technical changes as an exogenous factor and the basic mechanism of economic growth. As changes in productivity are of exogenous nature, according to Solow, they are regarded as a result of conscious activity of economic actors; hence, the change in productivity should be analyzed through mechanisms which generate better productivity as well as through the factors which indicatively result in long-term differences between countries (Jones, Manuelli, 2004: 3).

Neoclassicists explain the inequality of economic growth between countries from the standpoint of growth of production value, which is considered to be the result of observable growth in three factors: labor - through increase of education and employment; capital through increase in savings and investments, and technological innovations (Cvetanović, Leković, 2012: 190). This model of economic growth is illustrated in Formula 1.

Formula 1: The general form of production function in the neoclassical model of economic growth (Barro, Sala-i-Martin, 2004: 27).

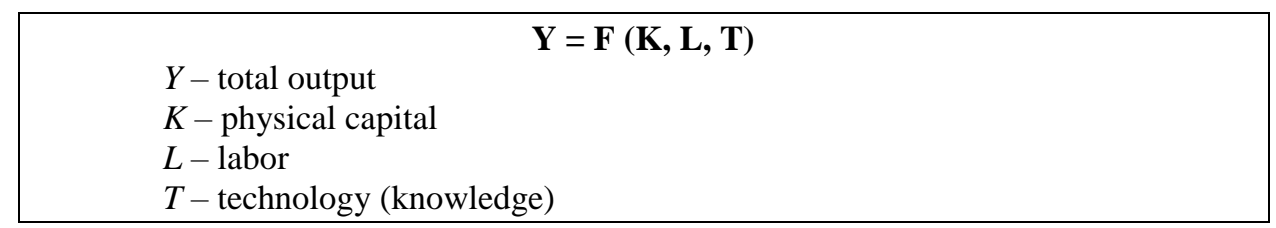

According to Barro and Sala-i-Martin (2004), economic growth is determined and conditioned by the role of production. It is considered to be neoclassical in nature if it entails the following characteristics: 
- Constant return of capital and labor;

- At a constant level of labor and technology, each additional increase of capital leads to projected increase of output, while these projections decrease with the increase in number of machines, i.e. technological changes. The same assumptions apply to labor as a factor of production;

- Inada (1963) conditions: Borderline product of capital or labor is getting nearer to infinity as capital, or work, is getting nearer to 0 , and vice versa;

- Essentiality: Inputs are regarded as an essential category of production process if a certain positive quantity of input is necessary for the equal quantity of output to be produced.

Starting from the unconditional convergence approach (which is based on decreasing yield on capital) and regarding technology as a public good (asset), neoclassicists believed that undeveloped countries with the same savings and investments rates, according to increase of capital productivity, gain all the comparative advantages to reach the level of developed countries (Cvetanović, Obradović, Đorđević, 2011: 3).

\section{ENDOGENOUS CHARACTER OF GROWTH}

As opposed to neoclassical views, endogenous theories regard economic growth through influence of endogenous factors. Neoclassical models of growth attributed work productivity growth to exogenous parameters, like technical innovations, which resulted in increase of capital, which on the other hand led to increase in production and consumption. Endogenous approach regards that same growth through endogenous processes, therefore instead of technical innovations, explicit creation of conditions of technical progress through intensified research and development areas of production is stated (Jones, Manuelli, 2004: 4). This model of economic growth is illustrated in Formula 2.

Formula 2: The general form of production function in the endogenous model of economic growth (Cvetanović, et al., 2011: 5)

$$
\begin{aligned}
& \quad \mathbf{Y}=\mathbf{F}(\mathbf{R}, \mathbf{K}, \mathbf{H}) \\
& Y-\text { total output; } \\
& R-\text { research and development; } \\
& K-\text { accumulated capital stock; } \\
& H \text { - accumulation of human capital (Romer 1994). }
\end{aligned}
$$

Stating the accumulation of human capital as one of the factors of productivity, endogenous theories annul the relationship between economic growth and decreasing yield on capital. They focus on technological changes as the crucial carrier of endogenous economic growth, which is achieved by constantly improving the existing workforce and creating conditions for technological advancement (Cvetanović, et al., 2011: 5).

\section{INSTITUTIONAL ASPECTS OF ECONOMIC GROWTH}

Having in mind the previous theories which did not pay any attention to institutions, in the past few years, economic theory has been shaped through institutional theory which is 
based on macroeconomic policy and institutions as factors of growth (Nallari, Griffith, 2011: 55).

It is often implied that enormous differences between national economies are built into economic and social institutions which determine the rules of functional and effective economy. Those rules are fundamental determinants of the organizational system of production and exchange, i.e. they are determinants of the diffusion of economic growth (Sengupta, 2011: 3).

In spite of ample attempts of economic theorists to explain the mechanisms of economic growth, it seems that there is no uniform explanation of the economic growth category. According to North and Thomas, innovations, volume economics, education and accumulation of human capital are not factors of economic growth, but they represent "growth" by themselves (Acemoglu, et al., 2004: 1). Thus, in their opinion, accumulation and innovations are singled out as direct sources of growth, whereby the comparison of economic growth is based on differences in institutions.

The influence of institutions can be understood only by considering the viability of prospective goals. The prospects of an economy are not based on reaching balance but on achieving future optimum which has not been achieved yet, due to dynamic changes of technical and technological advancement and new knowledge which change the past but affect future prospects as well (Reinert, 2006: 7).

\subsection{Influence of economic institutions on economic growth}

The influence of economic institutions on economic growth can be multiple. According to Chang, economic institutions should ensure investments in the means of production, social protection, as well as in macroeconomic stability. According to this author, various institutions can have the same function in different societies, when observed comparatively, but they can also have the same function within the same society but in various periods of development (Chang, 2007: 5). Such comprehension of multiple effects of institutions could be explained by the lack of proper relationship between the function and the institutional form.

Acemoglu, Johnson and Robinson examined the importance of economic institutions for economic growth through the influence on investing in physical and human capital, technology, but also through production organization (Acemoglu, et al., 2004: 2). Without disputing the importance of cultural and geographical factors for economic growth, these authors point out that the differences between economic institutions are the primary cause of inequality in economic growth and wellbeing in different countries.

Consequently, the influence of economic institutions can be currently observed by assessing the quality growth and, in the future, through the distribution of resources (Figure 1).

$$
\begin{aligned}
& \text { Economic } \\
& \text { institutions }_{t}
\end{aligned}\left\{\begin{array}{l}
\begin{array}{l}
\text { Economic results } \\
\end{array} \\
\text { Distribution of resources }{ }_{t+1} \\
(t-\text { current period, } t+1-\text { future })
\end{array}\right.
$$

Figure 1 Influence of economic institutions (Acemoglu, et al., 2004: 3) 
Therefore, distribution and allocation of resources are determined by the ownership structure and property relations, through explicit influence of economic institutions. This approach gets its verification in conditions of imperfection of the market mechanism which is the consequence of existance of transaction expenses and imperfection of information. Thus, institutions are verified as a key carrier of economic development in the extent by which they are able to reduce these expenses (Bardhan, 1989: 1389).

\subsection{Influence of political institutions on economic growth}

In the case of absence of transaction expenses, property rights are not considerable from the standpoint of gaining efficiency, since they could be changed and corrected with the aim of increasing production. Since transaction expenses are usually considerable, distribution of resources is more difficult due to the aforesaid market imperfection, which eventually contributes to the emergence of opportunistic behavior of economic actors (Bardhan, 1989: 1389).

Observing the development from the standpoint of the evolutionist approach, Sengupta states that it is determined, just like the production itself, by "the rules of the game" through the operation of the market system and the normative framework which is, among other things, the result of the dominant influence of the ruling structure (Sengupta, 2011: 3). This brings us to a new category of institutions - political institutions and the source of "political power".

In terms of power of political insitutions, Acemoglu et al. (2004: 4) differentiate de jure (according to law) and de facto (actual) political power, making a precise distinction from the standpoint of their influence on economic institutions and distribution of resource (Figure 2).

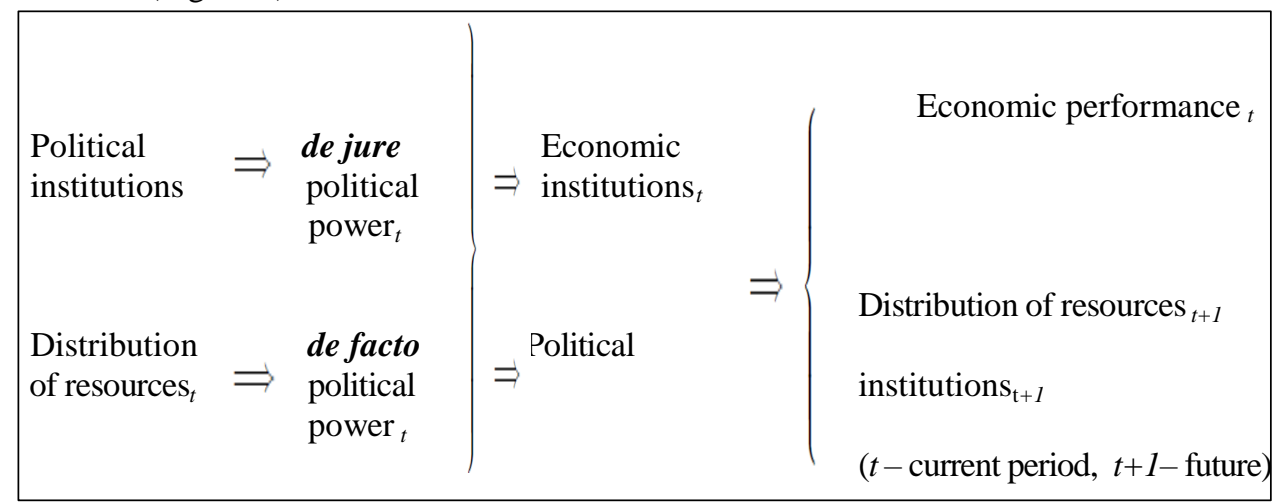

Fig. 2 Influence of political institutions (Acemoglu, et al., 2004: 6)

According to Acemoglu et al. (2004: 5), the endogenous character of economic institutions leads to observing them through the matter of collective choice, where political power is stated as a determinant which defines the choice of economic institutions in a society. As different economic institutions determine the distribution of resources, in case of conflicts in interest, the choice will depend on the political rule. Political ruling is of an endogenous character as well, which further leads to the differentiation of de jure political power that stems from political institutions and their current action through determining the form of ruling and limiting the power of the political elite. 
The institutional system results in de jure political ruling which explicitly affects the choice of economic institutions. However, de facto political power is also present in the society but it does not stem from institutional activities of political institutions; it is actually connected with activities of an individual or groups that have political power. This form of political power stems from the capacity of an individual or a group of individuals acting together to impose their interests on society. De facto political power depends on economic resources of those individuals or groups, by which they implicitly affect the actions and choice of political institutions in the future (Figure 2).

\section{CONCLUSION}

All things considered, the neoclassical approach in its core starts from a perfect economic system which does not recognize the impact of economic exteralities. That kind of approach is not realistic: it hinders the comparative analysis of long-term growth between the countries, and it regarded as a fundamental reason that precludes endeavours to explain the difference in economic growth between undeveloped and developed countries.

Economic externalities, such as imperfect competition and underemployment, have conditioned the emergence of a new approach to explaining economic growth which starts from the standpoint of endogenous factors. Thus, economic growth is explained by examining the factors operating strictly within the frame of the economic system itself.

The significance of technological advancement for economic growth has been stated ever since Joseph Schumpeter introduced the concept of "creative destruction" as the force behind long-term economic growth. A model cannot generate economic growth unless it is based on endogenous technological advancement, which is nowadays defined as learning by doing (through work and practice). Among other things, technological advancement brings about structural transformation, and technology is stated as a key factor of production cycle which may compensate for the limitations of certain actors and thus enable economic growth.

Within the domain of neoclassical and endogenous theories, economist endeavoured to understand the complex nature of economic growth and development. Unequal economic growth and development of world economy were explained through factors of production. Yet, from the stanpoint of institutional theory, this kind of approach is incomplete.

Modern economic growth and prosperity are part of complementary activities of economic and political institutions. According to modern theories of economic growth, the exclusion of institutions (both economic and political ones) leads to stagnation and poverty. However, history has proven that economic growth is possible even without including economic institutions if their impact is compensated by the influence of the political elite through placing funds into hyperproductive activities which are under the control of the political elite. 


\section{REFERENCES}

Acemoglu, D., Johnson, S., Robinson, J., (2004). Institutions as the fundamental cause of long-run growth, National bureau of economic research, Cambridge.

Barro, R. J., Sala-i-Martin, X., (2004). Economic Growth, The MIT PressCambridge, Massachusetts London, England.

Bardhan, P., (1989). The New Institutional Economics and Development Theory: A Brief Critical Assessment, World Development, Vol. 17, No. 9, pp. 1389-1395.

Cvetanović, S., Obradović, S., Đorđević, M., (2011). Hipoteza o konvergenciji u endogenim teorijama rasta (Convergence Hypothesis in Endogenous Growth Theories), Ekonomske teme, XLIX, No. 1, Niš, pp. 1-13,

Cvetanović, S., Leković, V., (2012). Tehnološka prelivanja putem stranih direktnih investicija i endogeni ekonomski rast (Technology spillovers through foreign direct investment and endogenous economic growth), Teme, TM, G. XXXVI No. 1, pp. $187-204$, Niš.

Chang, H., (2007). Institutional change and economic development, Faculty of Economics, University of Cambridge.

Jones, L. E., Manuelli, R. E., (2004). Neoclassical Models of Endogenous Growth: The Effects of Fiscal Policy, Innovation and Fluctuations, Federal Reserve Bank of Minneapolis.

Nallari, R., Griffith, B., (2011). Understanding Growth and Poverty: Theory, Policy, and Empirics, The International Bank for Reconstruction and Development / The World Bank.

Sengupta, J., (2011). Understanding Economic Growth, University of California, Santa Barbara College of Letters \& Science, Dept. Economics.

Reinert, E. S., (2006). Institutionalism ancient, old and new, A Historical Perspective on Institutions and Uneven Development, research paper no. 2006/77.

\section{URAVNOTEŽEN PRIVREDNI RAST SA STANOVIŠTA SAVREMENIH TEORIJA RASTA}

Svetska ekonomija, decenijama unazad, prolazi kroz određene procese koji se kreću relacijom ekspanzija - stagnacija. Tako su elementi, odnosno uzroci privrednog razvoja, ključno pitanje koje datira još od sedamesetih godina i Adama Smita. Nacionalne ekonomije integrisane kroz svetsku ekonomiju prolaze kroz neku od transformacija koja se eksplicitno može objasniti posmatranjem kvaliteta privrednog rasta. Tako na jednoj strani imamo regione sa održivim razvojem i uravnoteženim privrednim rastom, ali i ekonomije koje se svojom ekspanzijom kategorišu kao zemlje u razvoju. Distorzija svetske ekonomije, posmatrana kroz privredni rast i nejednakost nacionalnih ekonomija, sa stanovišta ekonomske teorije može se eksplicirati različitim modelima privrednog rasta.

Ključne reči: privredni razvoj, uravnotežen privredni rast, nejednakost, modeli privrednog rasta.

Proofreading and copy-editing:

Gordana Ignjatović 